DOI: $10.1515 /$ hssr -2017-0013

\title{
Ship Breaking Industries and their Impacts on the Local People and Environment of Coastal Areas of Bangladesh
}

\author{
Md. Juel Rana Kutub ${ }^{1}$, Nishat Falgunee**, Shahreen Muntaha Nawfee*** \\ and Yasin Wahid Rabby ${ }^{* * * *}$ \\ Faujdarhat Cadet College, Bangladesh
}

\begin{abstract}
The coastal area of Bangladesh is one of the most ecologically productive and it contains a rich biodiversity which includes several species that are endemic to this region. Much attention has been focused on ship breaking industries in the coastal areas because of the threat they pose to this thriving biological communities along with their other environmental impacts and the perilous working environment of the workers. The coastal environment of Sitakunda is severely contaminated by various processes related to shipbreaking i.e. the disposal of different toxic wastes into the sea water, deforestation by expanding ship breaking yard, changing land-use pattern and release of toxic substance into the soil. Moreover, the workers of this industry are exposed to an extremely risky and toxic working environment which makes them vulnerable to both physical and psychological disorder as well as to accidental deaths and injury. Still, workers embrace these risks for very poor wages and most of the profits go to the already rich businessmen. Despite various negativities, this industry has gained importance due to the increasing demand of raw material for re-rolling industries and employment opportunities for the people of the coastal areas.
\end{abstract}

*Lecturer, Department of Geography, Faujdarhat Cadet College, N1, Salimpur, Bangladesh; email: Juelrana63@yahoo.com

** Department of Geography and Environment, University of Dhaka, Bangladesh; email: nishatfalgunee@gmail.com

${ }^{* * *}$ Department of Geography and Environment, University of Dhaka, Bangladesh; Email: smnawfee@gmail.com

${ }^{* * * *}$ Department of Geography and Environment, University of Dhaka, Bangladesh; email: yashinwahidr7@gmail.com 
As this industry is indispensable due to its importance in the macro and micro economy of Bangladesh, a sustainable management approach should be taken to at least minimize the environmental and health impacts of ship breaking industries. The current paper aims to investigate the extent to which this industry is affecting the ship breaking yard labors and the environment, despite the growing concern nationally and internationally, and it uses both primary and secondary data.

Keywords

Ship breaking activities, Environmental impact, Health impact, Pollution, Safety of workers, Coastal management

\section{Introduction}

World Bank chief economist Lawrence Summers enunciated his opinion in 1991 that "the economic logic behind dumping a load of toxic waste in the lowest wage country is impeccable" (Paul, 2004). This statement was leaked later in the press. Summers suggested the international trade as a way to deal with the problem of hazardous waste disposal to the developing and underdeveloped countries. Every year about 400 million tons of toxic waste is produced in the world and 98 percent of it is produced by the OECD (Organization for Economic Cooperation and Development) countries (Tom, 1994). OECD countries consist of 30 developed countries and the USA alone produces 75 percent of hazardous waste. During the 1970s OECD countries started to adopt an environmental movement which increased the cost of hazardous waste treatment and disposal (Michael, 1999). This increasing disposal cost of waste forced countries to look for alternative options. Then a new waste dumping market in South Asia emerged during the 1990s and at present, this region is the dominant importer of hazardous waste from OECD countries (Ranawana et al, 1996). South Asian countries are economically backward and burdened by a towering unemployment problem which has compelled them to import hazardous waste. Due to the flexibility of the law enforcement sector, the cost of waste disposal in this region is lower than in developed countries (The Economist, 15 Feb, 1995). Michael Rauscher, an environmental specialist from University of Rostock's Institute of Economics, stated that less 
Juel Rana Kutub, Nishat Falgunee..., Ship Breaking Industries...

developed countries are willing to accept these toxic wastes for low compensation payments (Zada, 1998). South Asian countries place higher value on economic development rather than on environmental protection or labor justice. One of the ways of disposing toxic substances has given rise to the ship breaking industry in South Asian countries.

The ship breaking industry flourished in Bangladesh in 1984. Since then the country has developed one of the largest ship breaking industries in the world. National demands for iron, the generation of revenue and employment opportunities for the working poor are the main causes behind the quick growth of this industry. However, the industry causes severe disruption to the natural coastal environment and poses a substantial threat to workers' health. The lack of environmental laws and regulations, as well as occupational health security guidelines, has worsened the situation in Bangladesh.

The ship breaking industry is concentrated along the elongated seabeach of Sitakunda in Chittagong. The local people there are mostly poor and uneducated. As a result, in spite of the frequent deaths and injuries, they are attracted to the working opportunities in the ship breaking industry for their livelihood. Maximum deaths take place from explosion in the oil tanker (Iqbal, 2012). Moreover the laborers as well as local people suffer from serious diseases caused by air, water and soil pollution caused by this industry.

The industry severely threatens the surrounding natural environment as hazardous wastes are released from the broken ships and dumped into the adjacent area without following any proper waste management system. Consequently, the soil, air and water of the ship breaking areas are severely polluted and the biodiversity of the terrestrial and marine habitat are threatened. Furthermore, trees are cut down to provide space for more recycling projects, which augments the negative impact of this industry on the environment.

Over the last few decades, the concern for the development of an environmentally safe ship breaking and recycling industry, as well as to ensure occupational health safety, has risen. Bangladesh has become a signatory of the Basel Convention which pleas to prevent transport of hazardous substances. Besides, there are an Environment Conservation 
act, rules and laws which hope to influence the growth of an environmentally sustainable ship breaking industry. However, how much are these laws and regulations followed? The current paper aims to investigate the extent to which this industry is affecting workers and the environment, despite the growing concern, nationally and internationally. It also compiles findings of other researchers into a single platform in the matter of environmental impacts.

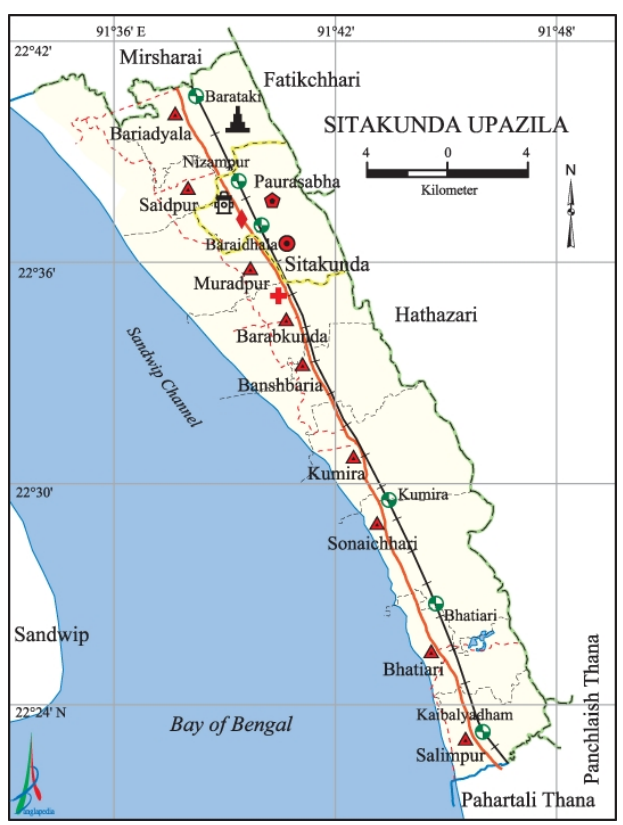

\section{Study Area}

The ship breaking industry in Bangladesh is concentrated in Bhatiary to Barwalia Upazilla (an Administrative Unit of Bangladesh) of Sitakunda in Chittagong District. The favorable geographical location (22 $37^{\prime} 99^{\prime \prime}$ N Latitude and $91^{\circ} 33^{\prime} 05^{\prime \prime}$. E Longitude) and the curved shape of the Bay of Bengal has fostered the establishment and flourishing of ship breaking activities in Sitakunda.

Figure1: Sitakunda Upazilla

(Banglapedia, 2012)

\section{Methodology}

The study was based on the combination of primary and secondary sources of data. The primary data were collected through direct field observations, focused group discussions (FGD), and face to face interviews with a questionnaire survey. Data collection was done in two phases, one of which took place in 2012 and other processes were done in 2015. Groups that were surveyed were laborers, customers, local village victims, NGO officials and ship breaking business owners, and the number of respondents was 50 . Secondary data that were collected and analyzed included different journal articles, newspapers, magazines, 
Juel Rana Kutub, Nishat Falgunee..., Ship Breaking Industries...

HSS, vol. VI, no. 2 (2017): 35-58

books, City Corporation data, GO \& NGOs and TV reports and documentaries. The tools used were SPSS, MS Excel, Google Earth, ARC GIS 10 and MS Word.

\section{Limitations of the study}

The study was constrained by financial limitations. Also, data collection was hindered by respondents' non-cooperation. It was very hard to find respondents because workers and related officials are forbidden to talk about what goes on in these locations. Fearing for their jobs, most of the people denied access to data and interviews.

\section{Results and Findings}

The coastal belt at Sitakunda in Chittagong district remains littered with scrap metals stained with toxic chemicals and oils. Deaths and stories of accidents at ship breaking yards are frequent but few get reported officially to the people. Rezwana Hasan, the director of Bangladesh Environmental Lawyers Association (BELA) moved to ban the ship breaking industries in 2009 and the Supreme Court ordered the Ministry of Environment and Forest to take steps against it. Despite these steps, ship breaking activities rose dramatically and the unlawful activities are still going on. At present, there are about 150 ship breaking yards in Sitakunda and 70 of them are operational. More than 25,000 laborers are directly working in the ship breaking yards in Sitakunda (YPSA, 2005). On the surface, ship breaking seems to be an ideal industry which is boosting the economy of the country. However, at the back of the high wall, piles of metal sheets, rusty pipes and toxic black oil are strewn across the rough ground along the coast of Bay of Bengal near Sitakunda. The ship breaking industry is responsible for the degradation of the coastal environment in Bangladesh. Over the last 20 years, the ship breaking industry has expanded drastically and chaotically; its working conditions are hazardous to the workers' health, and its impacts are hostile towards the environment. The level of ship breaking activities is measured in terms of Light Displacement Ton (LDT). LDT is the weight of the ship without any cargo on the board and it determines the value of a ship. Bangladesh is playing a central role in the growth of ship breaking industries. Around 23\% of total LDT ship 
Juel Rana Kutub, Nishat Falgunee..., Ship Breaking Industries...

HSS, vol. VI, no. 2 (2017): 35-58

breaking in the world is done in Sitakunda, which shows Bangladesh's dominance in this sector.

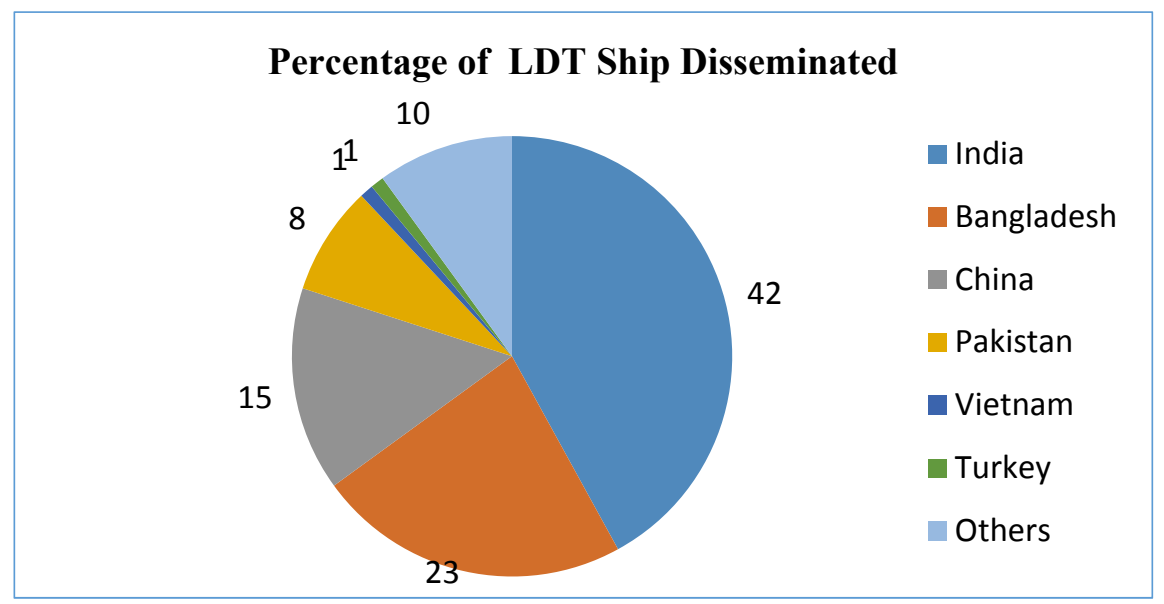

Figure 2: Ship Recycling Volumes (LDT) by Country from 1994 to 2009 (NCSG, 2011)

\subsection{Impact on Local Workers}

To understand the situation in its entirety, it is essential to know the socio-economic conditions of the workers involved in ship-breaking.

\subsubsection{Socio-Economic Condition of Ship Breaking Workers}

The major portion of laborers (41.75\%) falls under the age group of 19-22. Around 11 percent of the labor force is children and minors i.e. under 18 years old. Yet, the entire ship breaking industry publicizes with a sign board on which "no child labor is in this yard" is written. According to the local NGOs YPSA and FIDH, most of the child laborers come from the northern part of the country, which is comparatively backward in economic development. A senior official in charge of inspecting the yards from the Inspection Department for Factories and Establishment denied the accusation of having child labor in ship breaking yards in Sitakunda. He retorted that, "the problem is that, the workers look younger than their actual age and I have never seen child labor in the yards" (Child Breaking Yard Report, 2009). This 
type of comment is an insult to the intelligence of the society. Moving on, laborers whose age exceeds 30 consist of only 10 percent of the workforce due to their lessened physical strength and capability as ship breaking activities is a muscle based work and as a result no female workers is seen on the site.

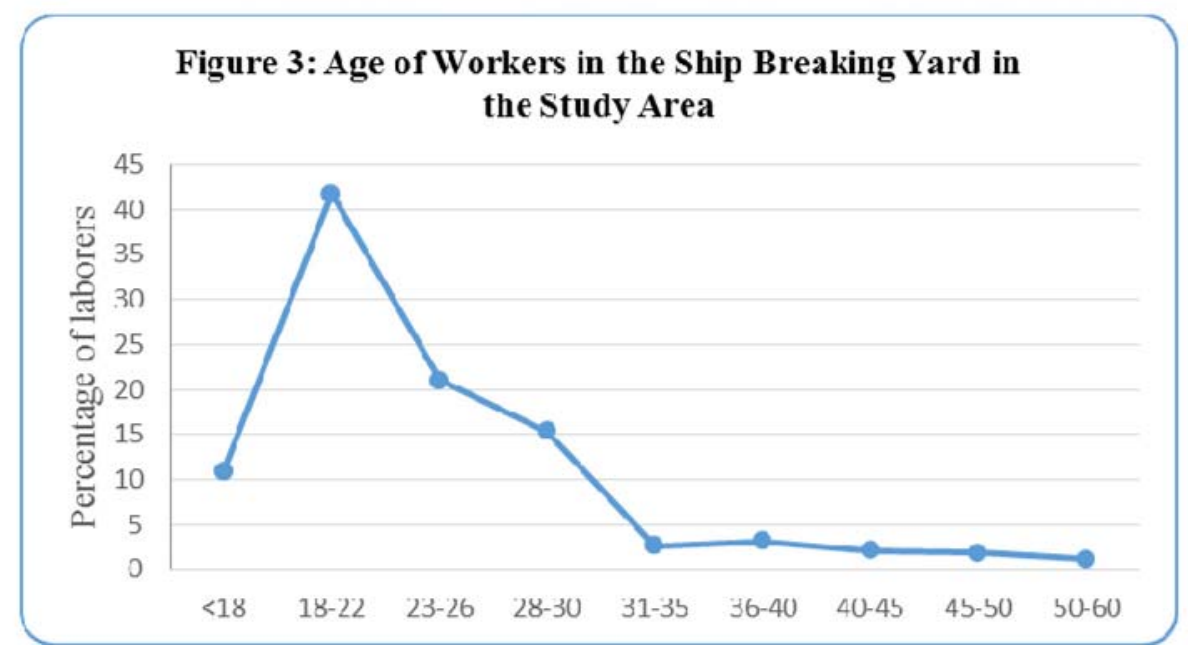

All workers in the ship breaking yard are male due to the high risk and hard nature of the job. Two thirds of the laborers are married, which entails that they are in charge of supporting their family, whereas the unmarried ones are child laborers who are forced to work to support themselves and their families.

Most of the laborers are from northern Bangladesh due to the underdeveloped economic condition, the lack of employment and education in the region. More than 50 percent of the labor force comes from the northern districts of Bogra, Dinajpur, Rangpur etc. Only onefourth of the labor forces have their hometown in and around the shipbreaking sites that is the southern parts of Bangladesh. The majority of the laborers have brought along their family and rent houses in Sitakunda. 
Juel Rana Kutub, Nishat Falgunee..., Ship Breaking Industries... HSS, vol. VI, no. 2 (2017): 35-58

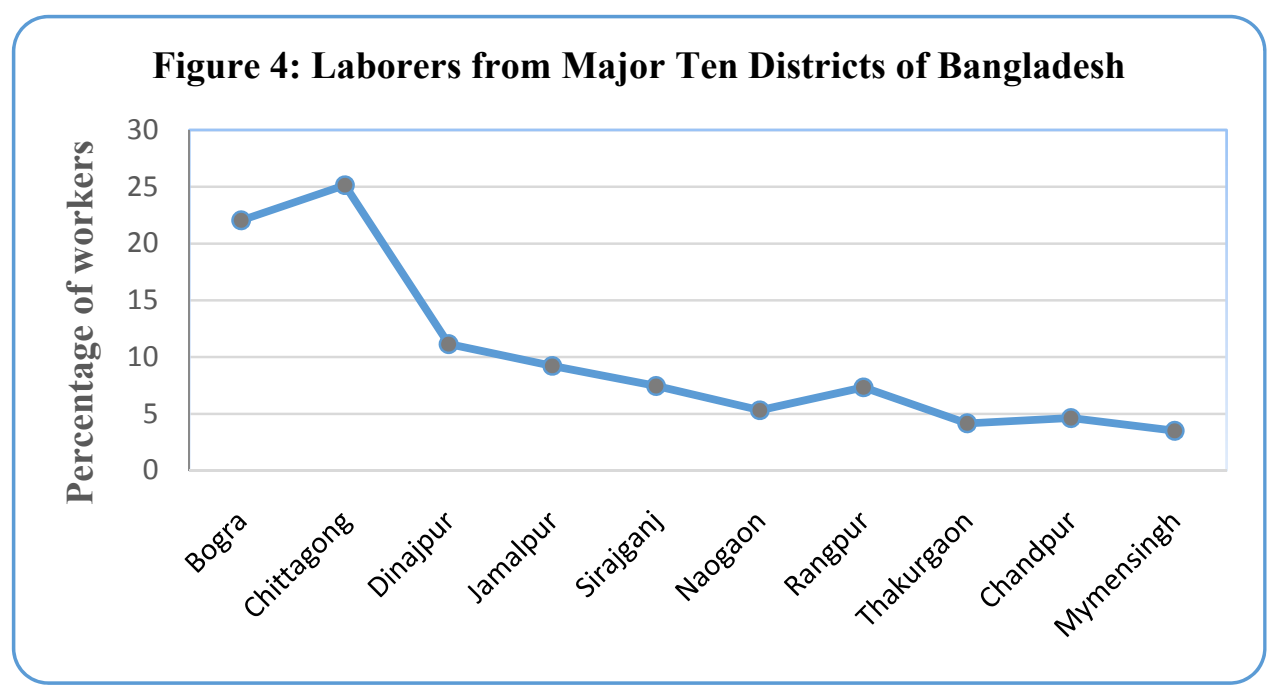

As far as the educational status of the workers is concerned, it is clear from figure 5 that almost half of the laborers are illiterate and two fifth have just primary level education. Workers with secondary or higher education comprise only 10 percent of the total ship breaking yard workforce. This appalling educational status compels them to work with low wages; also, the ship breaking sector offers fewer opportunities for educated, skilled and expert workers.

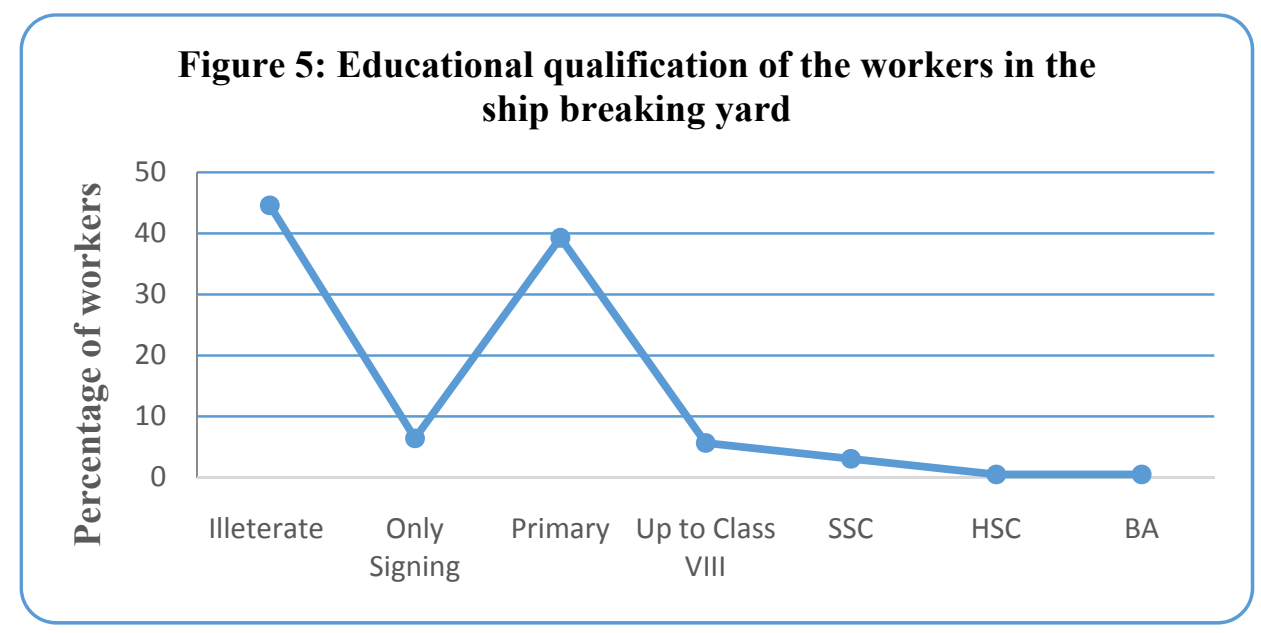




\subsubsection{Working Conditions of Ship Breaking Industry Workers}

The laborers of the ship breaking industries have to work in a hostile and hazardous environment, with scant facilities. Almost everyone denied that the food, sanitation, housing and working environment can be described as very good. In case of food, three fifth said that the food was not good; one-fifth said that it was good and another fifth said that the food was very bad. In the case of sanitation, $65.84 \%$ stated that the facility was very bad. Most of the workers (67.42\%) said that their living place and house is not good and only 14.71 said they have good housing facility. In Bangladesh, the most dangerous and risky working place is probably the ship breaking yard. About 3 of every 5 workers and 2 of every 5 workers stated that they have a not good and very bad working environment respectively, in the ship breaking yard of Sitakunda.

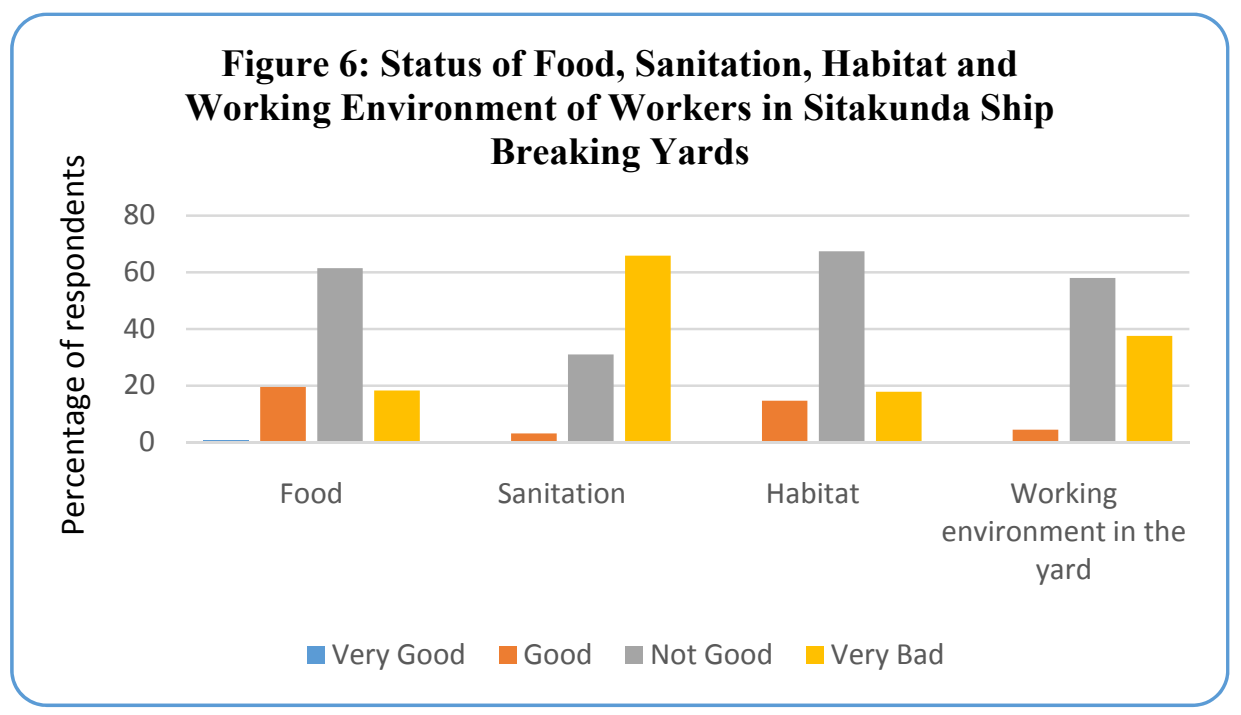

The wages of the laborers in the study area vary depending on workers' working hours and individual skill. The cutter group got the highest salary (215 taka per day) due to their nature of their work in terms of risk and importance. The plate group got an average 155 taka, the wire group 175 taka, the hammer group 210 taka and the foreman group 205 taka per day. Only the foreman got monthly salary and their job is less risky and easier than others. 
Juel Rana Kutub, Nishat Falgunee..., Ship Breaking Industries...

HSS, vol. VI, no. 2 (2017): 35-58

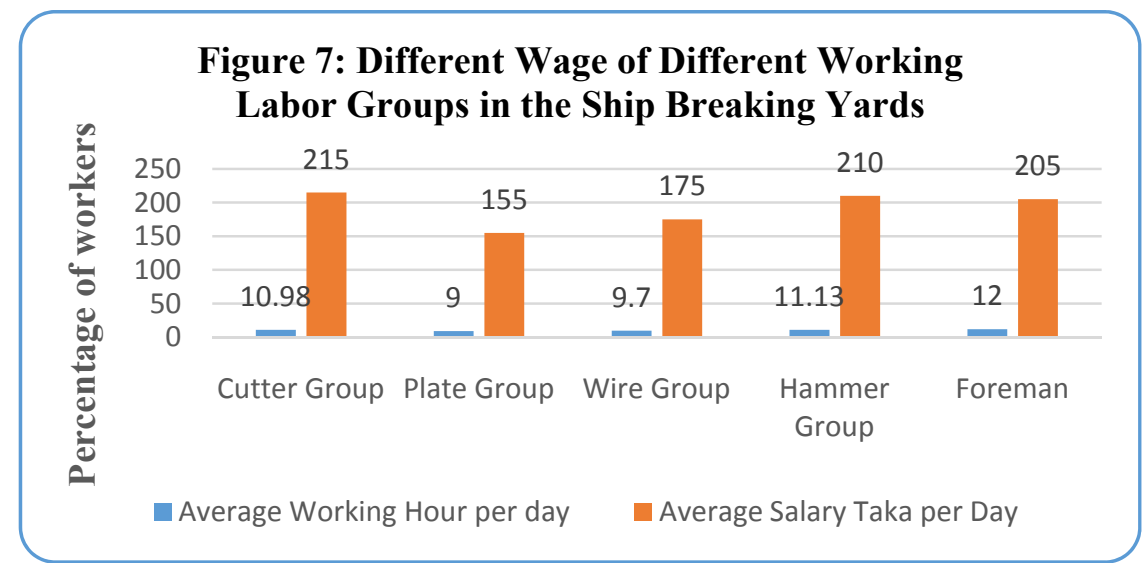

It is clear from figure 8 that most of the laborers $(62.87 \%)$ did not get any facilities, $22.18 \%$ got overtime facilities, a meager $5.27 \%$ got medical facilities and only $2.17 \%$ got increment facilities.

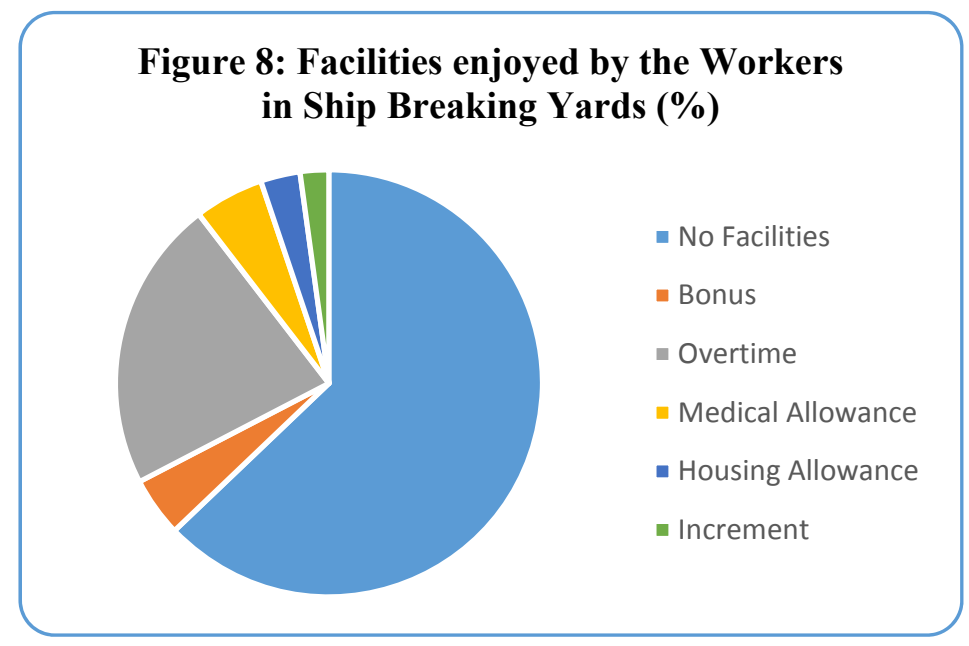

Most workers in the ship breaking industry got very few opportunities for leisure activities as they have to work an average of 10 hours a day to hold their jobs. Most of the laborers passed their leisure time by watching TV while few others enjoy singing, doing sports and going to cinemas. Visiting relatives is the second most popular leisure activity. 
Juel Rana Kutub, Nishat Falgunee..., Ship Breaking Industries...

HSS, vol. VI, no. 2 (2017): 35-58

Figure 9: Leisure Activities of Workers in Ship Breaking Industries of Sitakunda

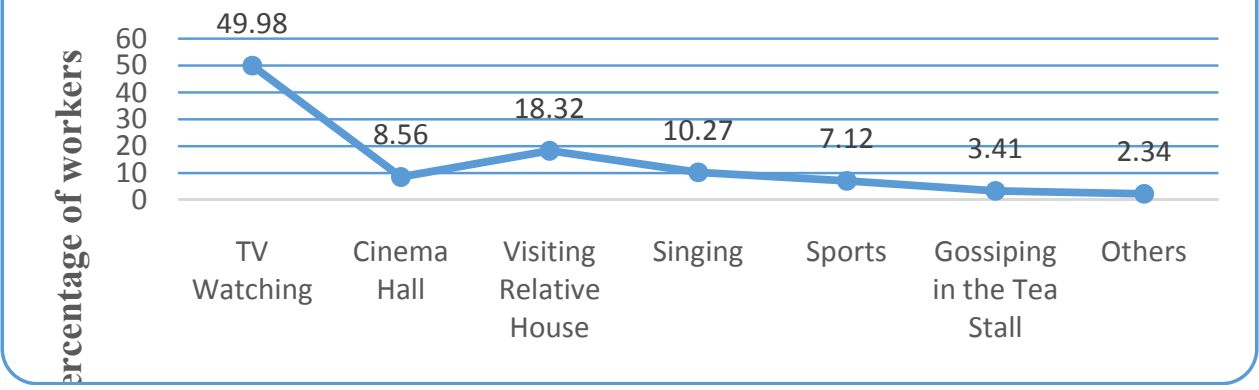

\subsubsection{Risk of Death, Injury and Health Hazards}

Workers in the ship breaking yard have to work in the hostile environment bearing the tension of sudden death or injuries. The problems they face are the risk of accidental injury and death, the lack of drinking water, the unbearable workload, low wages, the lack of working and safety equipment etc.

The workers of the ship breaking industries have to work in a hostile environment with toxic substances like asbestos, thus they suffered from overall cancer, esophagus cancer, trachea bronchus and lung cancer etc (Wu et al, 2015 and Muhibbulahh et al, 2014). In case of the injuries and diseases suffered by the workers in the Sitakunda ship breaking yards, the loss of body parts is the most serious one. Among the respondents, $22.31 \%$ lost their body organs, $16.97 \%$ witnessed spot deaths, and $13.83 \%$ suffered from skin diseases, $11.74 \%$ suffered from physical weakness and chest pain and 3.26\% were affected by cancer. The major causes behind all these sufferings are toxic gas explosion, toxic oil spilling, the lack of safety equipment, too much heat, a polluted environment, sparks and fires, stressful work, the lack of training, smog and dust etc. 


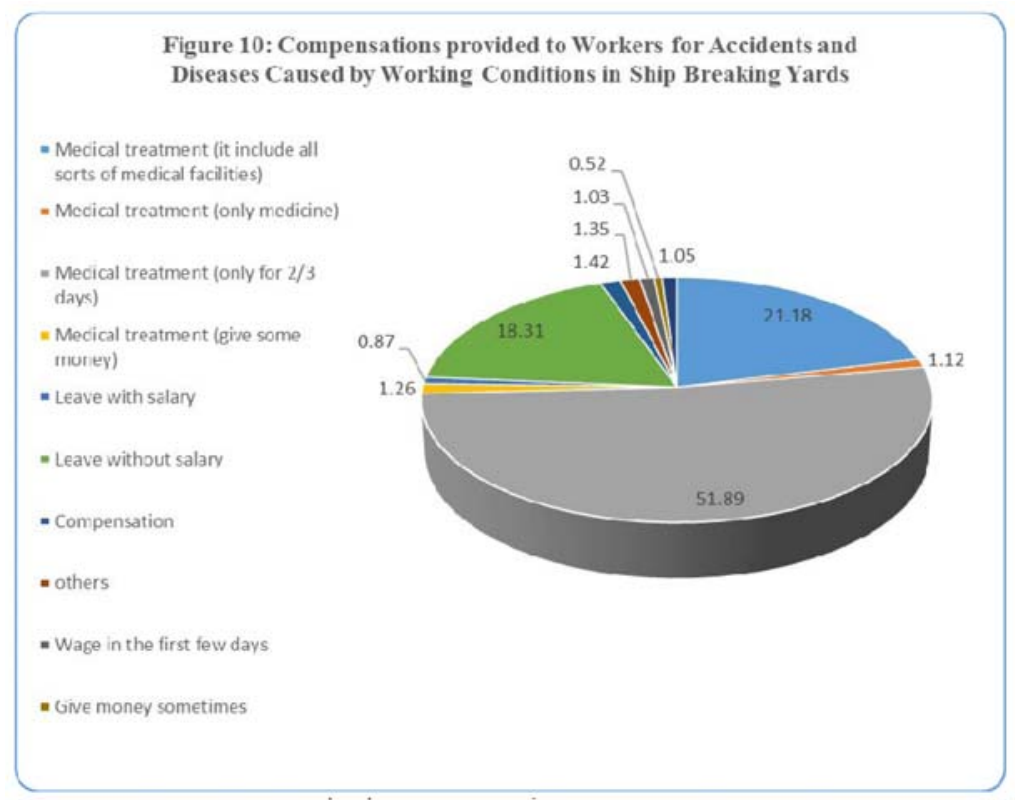

International Labor Organization (ILO) endorsed a code on occupational safety and health in ship breaking during the $279^{\text {th }}$ session of the ILO's Governing Body (November, 2000) and it stated that governments should be encouraged to have an inventory of hazardous material related with ship breaking activities. The International Maritime Organization (IMO) also endorsed the workers safety and health safety during ship breaking activities in 1998 at the $43^{\text {rd }}$ session of the Marine Environmental Protection Committee (MPEC 43) in Norway (Anderson, 2001). As a signatory of ILO and IMO, Bangladesh is supposed to follow the rules. But most of the ships breaking yards owners do not comply with these regulations and government officials also turn a blind eye to these anomalies. The workers are not even properly compensated for their injuries and health conditions caused by the unsafe and unhealthy conditions in the ship breaking yards. Only 1 in 5 workers got complete medical treatment facilities while more than half injured workers got medical treatment for the first 2 or 3 days. One fifth of them got leave without any payment or compensation. Moreover, after recovery, most did not get their job back or were not provided with any kind of rehabilitation facility. 
Juel Rana Kutub, Nishat Falgunee..., Ship Breaking Industries... HSS, vol. VI, no. 2 (2017): 35-58

Table 1: Hazards and Risks of Ship Breaking Activities of Workers in Sitakunda

\begin{tabular}{|c|c|c|}
\hline $\begin{array}{c}\text { Serial } \\
\text { No }\end{array}$ & $\begin{array}{l}\text { Major Categories } \\
\text { of Hazards }\end{array}$ & Mechanism of Hazards \\
\hline \multirow{10}{*}{01} & \multirow{10}{*}{$\begin{array}{l}\text { Serious Accident } \\
\text { Related Hazards }\end{array}$} & $\begin{array}{l}\text { Fire and outburst by explosive flammable } \\
\text { materials }\end{array}$ \\
\hline & & Being trapped by falling materials \\
\hline & & Squashed between heavy materials \\
\hline & & Snapping of cables, ropes, chains and slings \\
\hline & & $\begin{array}{l}\text { Handling heavy objects and poor access to } \\
\text { progressively dismantled vessels }\end{array}$ \\
\hline & & $\begin{array}{l}\text { Falls from height inside ship structure or on } \\
\text { the ground }\end{array}$ \\
\hline & & Stuck by moving objects \\
\hline & & Slipping on wet surface \\
\hline & & Spiky materials \\
\hline & & $\begin{array}{l}\text { Oxygen deficiency in confined space in the } \\
\text { ship }\end{array}$ \\
\hline \multirow{4}{*}{02} & \multirow{4}{*}{ Physical Hazards } & Noise pollution \\
\hline & & Tremendous temperature \\
\hline & & Vibration \\
\hline & & Poor illumination \\
\hline \multirow{8}{*}{03} & \multirow{8}{*}{$\begin{array}{l}\text { Mechanical } \\
\text { Hazards }\end{array}$} & Truck and transport vehicle accident \\
\hline & & Scaffolding, fixed and portable ladders \\
\hline & & Impact by any sharp edged tools \\
\hline & & $\begin{array}{l}\text { Power driven hand tools, saw and abrasive } \\
\text { cutting wheels }\end{array}$ \\
\hline & & Shackles, hooks and chains \\
\hline & & Cranes, winches and hauling equipment \\
\hline & & Lack of safety guard in machine \\
\hline & & $\begin{array}{l}\text { Unskilled maintenance of machine and } \\
\text { equipment }\end{array}$ \\
\hline \multirow{4}{*}{04} & \multirow{4}{*}{ Biological Hazards } & Poisonous marine organisms \\
\hline & & Risks of communicable diseases \\
\hline & & Bitten by snacks, insects and others \\
\hline & & Infectious diseases \\
\hline 05 & Economic and & Repetitive strain injuries, awkward postures, \\
\hline
\end{tabular}


Juel Rana Kutub, Nishat Falgunee..., Ship Breaking Industries...

HSS, vol. VI, no. 2 (2017): 35-58

\begin{tabular}{|l|l|l|}
\hline \multirow{3}{*}{$\begin{array}{l}\text { Psychological } \\
\text { Hazards }\end{array}$} & excessive work pressure and monotonousness \\
& $\begin{array}{l}\text { Lengthy working hours and shipment working } \\
\text { system }\end{array}$ \\
& $\begin{array}{l}\text { Mental stress and aggressive behavior and } \\
\text { violence }\end{array}$ \\
\cline { 2 - 2 } & $\begin{array}{l}\text { Deficiency, low wages, lack of awareness and } \\
\text { social environment }\end{array}$ \\
\hline
\end{tabular}

Table 1 summarizes the hazards and risks that laborers of ship breaking yards face constantly while working. Although the owners of these ship breaking yards were supposed to provide all kinds of treatment cost, rehabilitation and safety measures, the workers were left all alone on their own.

\subsection{The Impact of Ship Breaking Activities on the Coastal Environment in Sitakunda}

Unfortunately, the coast of Bangladesh is highly vulnerable to natural processes and anthropogenic activities (MEA, 2005; CZP 2005). Recently, concerns have risen regarding the impact of ship breaking industries on the coastal areas. Ships in Sitakunda are dismantled on the intertidal zone with low lying beach which discharges liquid, gaseous and solid pollutants (Demaria, 2010; Hossain and Islam, 2004; Islam and Hossain, 1986; Zou and Wei, 2010). It is impossible to prevent oil pollution and other liquid as well as solid contamination. The coastal soil, water and biodiversity are now highly degraded due to the unregulated ship breaking activities.

\subsubsection{Deforestation and Land Use Pattern Change}

Ship breaking industries flourished in Bangladesh due to the low dismantling cost, relaxed law enforcement and low labor costs. Ship breaking yards were present in $3.45 \mathrm{~km}$ strip of Sea beach in Sitakunda in 1989 which expanded to $12.78 \mathrm{~km}$ in 2010, which is 300 percent increase in coverage. The areal coverage also rose from 367 hectares in 1989 to 1,133 hectares in 2010, which also saw more than a 300\% rise. These figures clearly indicate the ever-increasing expansion of ship 
Juel Rana Kutub, Nishat Falgunee..., Ship Breaking Industries...

HSS, vol. VI, no. 2 (2017): 35-58

breaking yards in Sitakunda, which has caused deforestation and land-use pattern change in Sitakunda.

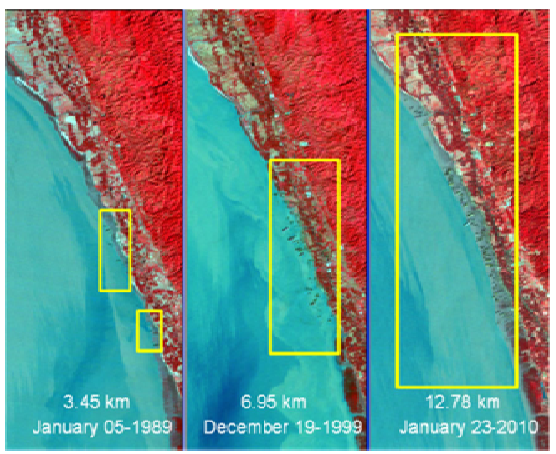

Figure 11: Expansion of ship breaking yards in Sitakunda (Abdullab et al, 2012)

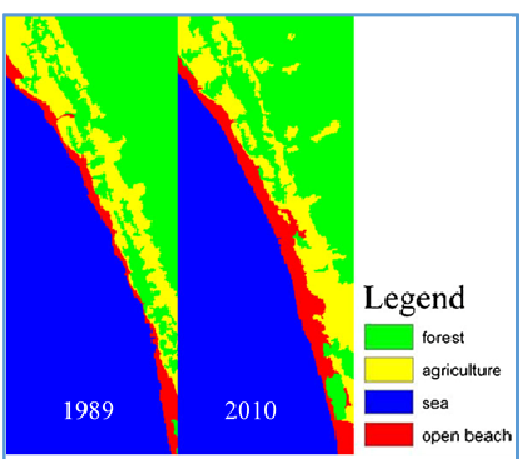

Figure 12: Land-use Change Sitakunda Ship Breaking Area (Abdullah et al, 2012)

Figure 13 illustrates that the new ship yard construction was the reason behind clearing forest area to gain easier access to open sea beach, and the croplands were converted to ship breaking yards. The circled areas are clear evidence of the degradation of forests and agricultural areas.
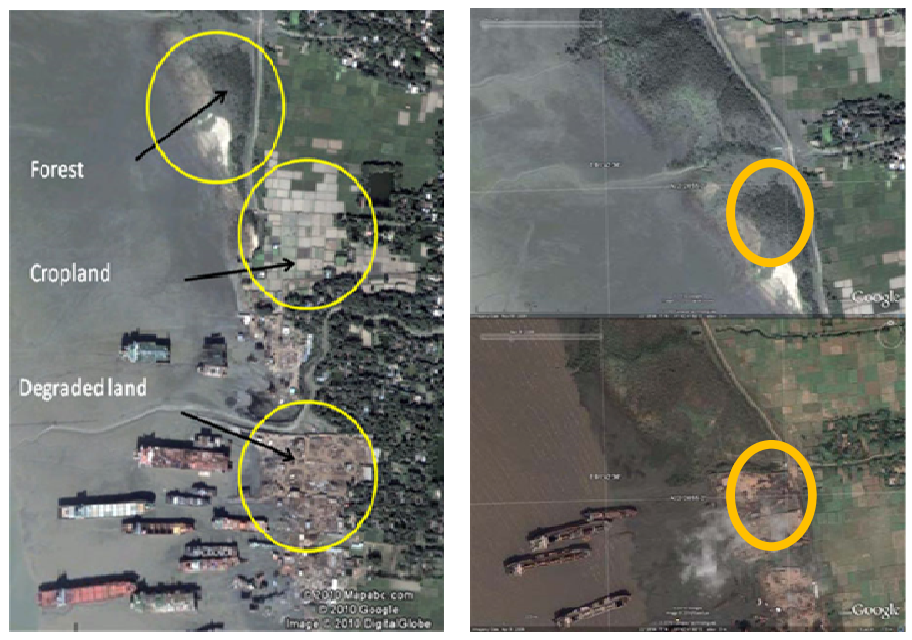

Figure 13: Degradation of Coastal Land, Forest and Cropland due to the Ship Breaking Activities in Sitakunda shown by circle (Image Source: Google Earth) 
Juel Rana Kutub, Nishat Falgunee..., Ship Breaking Industries...

HSS, vol. VI, no. 2 (2017): 35-58

\subsubsection{Physical-Chemical Properties of Soil and Water of Sitakunda Ship Breaking Area}

Trace metal concentration and physical-chemical properties studies help to find out the pollution trends and status of affected areas (Froster and Wittman, 1981). The trace metal concentration is higher than normal in the sea beach soil and water of Sitakunda ship breaking areas (Siddiquee et al 2009).

The trace metal and toxic substance concentration in the ship breaking areas of Sitakunda were found at higher levels than those recommended by GESAMP (Joint Group of Experts on the Scientific Aspects of Marine Pollution) in soil and water (YPSA, 2012).

The following table shows the trace metal concentration in sediments of Sitakunda.

Table 2: Trace Metal Concentration in the Sediments of Sitakunda Ship Breaking Area (Siddiquee et al, 2009)

\begin{tabular}{|l|l|l|l|l|l|l|l|l|l|}
\hline Site & $\begin{array}{l}\text { Sampling } \\
\text { Location }\end{array}$ & $\begin{array}{l}\mathrm{Mn} \\
(\mu \mathrm{g} / \mathrm{g})\end{array}$ & $\begin{array}{l}\mathrm{Cr} \\
(\mu \mathrm{g} / \mathrm{g})\end{array}$ & $\begin{array}{l}\mathrm{Ni} \\
(\mu \mathrm{g} / \mathrm{g})\end{array}$ & $\begin{array}{l}\mathrm{Zn} \\
(\mu \mathrm{g} / \mathrm{g})\end{array}$ & $\begin{array}{l}\mathrm{Pb} \\
(\mu \mathrm{g} / \mathrm{g})\end{array}$ & $\begin{array}{l}\mathrm{Cu} \\
(\mu \mathrm{g} / \mathrm{g})\end{array}$ & $\begin{array}{l}\mathrm{Cd} \\
(\mu \mathrm{g} / \mathrm{g})\end{array}$ & $\begin{array}{l}\mathrm{Hg} \\
(\mu \mathrm{g} / \mathrm{g})\end{array}$ \\
\hline Affected & Kumira & 2.32 & 22.89 & 25.36 & 119.86 & 41.57 & 28.01 & 0.59 & 0.05 \\
\hline Controlled & Sandwip & 1.8 & 19 & 3.98 & 22.22 & 8.82 & 2.05 & 0.19 & 0.02 \\
\hline
\end{tabular}

This toxic and polluted water and soil in the ship breaking yards of Sitakunda caused the disruption of forest coverage, marine biodiversity, land-use change, coastal erosion, frequent natural disaster and coastal pollution, i.e. the overall environmental degradation was ensued. The fish stock contaminated by toxic oil and trace metallic substance were then consumed by the people. It gave rise to human health hazards through a process called bio-magnification.

Table 3: Physico-Chemical Properties of Sea Water and Beach Soil Within and Outside Ship Breaking Areas (Hossain and Islam 2006)

\begin{tabular}{|l|l|l|l|}
\hline \multirow{2}{*}{$\begin{array}{c}\text { Physical-chemical } \\
\text { properties of } \\
\text { seawater }\end{array}$} & \multicolumn{3}{|c|}{ Sampling stations } \\
\cline { 2 - 4 } & Fauzdarhat & Kumira & Baroaoliar Mazar \\
\hline Turbidity (JTU) & 720 & 723 & 470 \\
\hline TSS (mgl- ${ }^{1}$ ) & 4195 & 4038 & 2284 \\
\hline TDS (mgl- ${ }^{-}$) & 1990 & 1982 & 1288 \\
\hline
\end{tabular}


Juel Rana Kutub, Nishat Falgunee..., Ship Breaking Industries... HSS, vol. VI, no. 2 (2017): 35-58

\begin{tabular}{|l|l|l|l|}
\hline PH & 7.8 & 7.7 & 7.2 \\
\hline EC $\left(\mu \mathrm{cm}^{-1}\right)$ & 1600 & 1710 & 3036 \\
\hline Chloride $\left(\mathrm{mgl}^{-1}\right)$ & 470 & 502 & 789 \\
\hline Iron $\left(\mathrm{mgl}^{-1}\right)$ & 36.02 & 37.62 & 2.26 \\
\hline Ammonia $\left(\mathrm{mgl}^{-1}\right)$ & 2.67 & 2.92 & 0.26 \\
\hline DO $\left(\mathrm{mgl}^{-}{ }^{-}\right)$ & 4.10 & 3.90 & 6.36 \\
\hline BOD $\left(\mathrm{mgl}^{-1}\right)$ & 7.63 & 6.98 & 4.08 \\
\hline Oil $\left(\mathrm{mgl}^{-}{ }^{-}\right)$ & 10,600 & 9,280 & Not done \\
\hline
\end{tabular}

\subsubsection{Impact on Biodiversity}

The higher concentration of trace metal and toxic substances in the environment of the ship breaking yard areas of Sitakunda hampered marine ecology and coastal ecology. The previously mentioned toxic substances impaired primary productivity by killing off the phytoplanktons and zooplanktons of the intertidal zones. In turn, the fish resources degraded severely due to the scarcity of food. Deforestation, polluted water and toxic soil destroyed and degraded the habitat, and thus threatened the growth of biodiversity in the study area.

\section{Table 4: Environmental Problems in the Ship Breaking Area of Sitakunda}

\begin{tabular}{|l|l|}
\hline \multicolumn{1}{|c|}{$\begin{array}{c}\text { Types of problems in the } \\
\text { Environment }\end{array}$} & \multicolumn{1}{c|}{ Percentage \% } \\
\hline Deforestation & 27.42 \\
\hline Less amount of fish catching & 13.89 \\
\hline Soil become so harder & 18.26 \\
\hline Agricultural production decreased & 8.29 \\
\hline Black and polluted water & 14.17 \\
\hline Land-use degradation & 2.23 \\
\hline Plants and animal degradation & 3.12 \\
\hline Toxic waste in the beach & 7.05 \\
\hline Smoke and bad smell in the air & 4.03 \\
\hline Others & 1.54 \\
\hline
\end{tabular}


Juel Rana Kutub, Nishat Falgunee..., Ship Breaking Industries...

HSS, vol. VI, no. 2 (2017): 35-58

Table 5: The Missing Fish Species in Ship Breaking Areas of Sitakunda (Siddique 2004; Alam et al, 1989)

\begin{tabular}{|l|l|l|l|}
\hline $\begin{array}{l}\text { Scientific name of } \\
\text { fish species }\end{array}$ & \multicolumn{1}{|c|}{ Local name } & $\begin{array}{l}\text { Scientific name of } \\
\text { fish species }\end{array}$ & Local name \\
\hline $\begin{array}{l}\text { Osteogeniosus } \\
\text { staenocephalus }\end{array}$ & Aspisoa katamach & Sphyraena obtusata & Khika mach \\
\hline Scolopsis vosmere & Nemipscol mach & $\begin{array}{l}\text { Carangoides } \\
\text { malabaricus }\end{array}$ & $\begin{array}{l}\text { Lohamuri } \\
\text { mach }\end{array}$ \\
\hline Eleotris fusca & Dora bailla & $\begin{array}{l}\text { Carangoides } \\
\text { melampygus }\end{array}$ & Bungda muri \\
\hline $\begin{array}{l}\text { Uranoscopus } \\
\text { guttatus }\end{array}$ & Foton mach & Sauridia elongata & Tiktiki mach \\
\hline russelli & Kala poa & $\begin{array}{l}\text { Anodontostoma } \\
\text { chacunda }\end{array}$ & Koiputi mach \\
\hline $\begin{array}{l}\text { Bahaba chaptis } \\
\text { Pricanthus } \\
\text { macracavthus }\end{array}$ & Prica mach \\
\hline $\begin{array}{l}\text { Pomadasys } \\
\text { Polynemus } \\
\text { sextarius }\end{array}$ & Grunti mach & Pricanthus tayenus & Prica mach \\
\hline Gobuis sadanandio & Nandi bailla & $\begin{array}{l}\text { Cynoglossus } \\
\text { macrolepidotus }\end{array}$ & $\begin{array}{l}\text { Lamba kukur } \\
\text { jib }\end{array}$ \\
\hline $\begin{array}{l}\text { Gobuis } \\
\text { melanosoma }\end{array}$ & Kalthu Bailla & $\begin{array}{l}\text { Apocryptes } \\
\text { serperaster }\end{array}$ & $\begin{array}{l}\text { Kata mach } \\
\text { masa }\end{array}$ \\
\hline Sphyraena forstegi & Khika mach & \multicolumn{1}{c|}{ chau } \\
\hline
\end{tabular}

\section{Conclusion and Recommendations}

Bangladesh is a country with zero mineral resource containing iron. But the country needs a huge amount of iron and steel for construction purposes and industrial development. OECD countries found a very cheap way to recycle their toxic wastes by exporting old ships into the South Asian countries where ineffective law enforcement, low labor cost and low ship dismantling cost makes ship breaking a lucrative business. Bangladesh has become a front runner in breaking old ships. The industry was initiated and it has expanded in Sitakunda at an exponential rate in the last two decades and Bangladesh has emerged as the second largest ship breaking country in the world (Jobaid et al, 2014). There are no specific rules and regulations of ship breaking activities in Bangladesh (Muhibbullah et al, 2014) to safeguard 
the workers from accidents, the loss of lives and body parts, and serious health hazards. There is a scarcity of pure drinking water, healthy food, hygiene toilet and good living conditions for workers in the ship breaking yards of Sitakunda, which are direct violations of laborer's rights.

In addition, ship breaking industries have severe impacts on the coastal environment of Sitakunda. Ship breaking activities have dire consequences on coastal biodiversity, soil, water, air, etc. There has been a large ecological imbalance in the study area due to the afore-mentioned activities. The concentration of organic chlorine, pesticides, toxic physical-chemical substance and the presence of toxic materials in the air, water and soil of the coastal areas, signified the level of environmental degradation. The areal expansion of this industry also caused deforestation and agricultural land degradation in the study area.

The ship breaking industries of Bangladesh have a significant contribution to the GDP, and for this reason the ship breaking industry cannot be stopped. The following recommendation has been drawn based on the above discussion for making ship breaking a sustainable and less environmentally unfavorable industry.

1) A sustainable Coastal Zone Management must be adapted to confined ship breaking industries in a particular area of the coast.

2) The government must ban the disposal for toxic waste into the sea and beach soil

3) National and Coastal authorities must comply with the policies of the International Maritime Organization for sustainable and less environment unfriendly ship dismantling.

4) Pre and Post Environmental Impact Assessment must be carried out from time to time to monitor and regulate ship breaking activities.

5) Employers must ensure adequate worker safety, refrain from hiring children and comply with the standards set by the International Labor Organization (ILO).

6) Following the theme "Safety First", every ship has to be inspected properly by an expert team. Only the ships with 'toxic gas and waste free certificate' should be allowed to dismantle.

7) Any kinds of accidents and injury of workers have to be cared for by providing medical facilities, compensation and insurance coverage by the ship breaking authorities. 
8) The government has to ensure the stricter law enforcement and minimum environment pollution should be in high concern while making any policies in the ship breaking industry.

9) Government Organizations, NGOs, INGOs and civil society has to come forward and raise their voice to ensure the basic rights of workers and their family.

10) The government has to ensure compliance with the rules and regulations of the International Maritime Organization (IMO) and the "Hong Kong International Convention for safe and environmentally sound recycling of ships".

\section{References}

Abdullah, H. M., Mahboob, M. G., \& Biruni, A. A. (2010). 'Drastic expansion of ship breaking yard in Bangladesh: a cancerous tumor to the coastal environment'. Proceedings of the International Conference on Environmental Aspects of Bangladesh (ICEAB), Sept. 4, 2010, University of Kitakyushu, Fukuoka, Japan, 2010, pp. 234-237. Available at:http://www.benjapan.org/ iceab10/64.pdf. Accessed 15 July 2015.

Abdullah, H. M., Mahboob, M. G., Banu, M. R., \& Seker, D. Z. (2013). Monitoring the drastic growth of ship breaking yards in Sitakunda: a threat to the coastal environment of Bangladesh. Environmental Monitoring and Assessment, 185(5), 3839-51. doi:10.1007/s10661-012-2833-4

Ahmed, A. (2011). Some of the major environmental problems relating to land use changes in the coastal areas of Bangladesh: A review, Joumal of Geography and Regional Planning 4(January), 1-8.

Ajello, Robin, and Arjuna, Ranawana. (1996). "Death in Slow Motion", Asia week, September. 20, 1996, p. 1.

Azad, A. K., Jensen, R. K., \& Lin, C. K. (2009). Coastal aquaculture development in Bangladesh: unsustainable and sustainable experiences. Environmental Management, 44, 800-809. doi:10.1007/s00267-009-9356-y.

Chang,Yen-Chiang., Onur, Nannan, W., \& Durak, S. (2010). Ship recycling and marine pollution. Maritime Faculty, Istanbul Technical University, Istanbul 34940. Available at: https://www.ncbi.nlm.nih.gov/pubmed/20594562.

Courtice, M. N., Demers, P. A., Takaro, T. I. M. K., Vedal, S., Ahmad, S. K. A., Siddique, Z., \& Davies, H. W. (n.d.). Asbestos-Related Disease in Bangladeshi Ship Breakers: A Pilot Study, 144-153 Taylor \& Francis Online,Volume 17, 
2011. Available at: http://www.tandfonline.com/doi/citedby/10.1179 $/ 107735211799030951$ ?scroll=top\&needAccess $=$ true

Department of Environment (DOE). (2007). Bangladesh: National Programme of Action for protection of the coastal and marine environment from land-based activities. Department of Environment, Ministry of Environment and Forests, Government of the People's Republic of Bangladesh, p. 52. Available at: http://www.doe-bd.org/npa_draft.pdf Accessed 15 July 2015.

European Commission (EC). (2007). Ship dismantling and pre cleaning of ships.

European Commission Directorate General Environment Report no. 6462202-1, issue 2. Farming, p. 83.

European Commission. (2012). Commission Staff Working Document Impact Assessment. Brussels, (March).

Feringa, G. (2005). Ship recycling in Bangladesh-findings of baseline survey. Draft Report to the ILO, Geneva.

Foysal, Q. O. (2009). Shipbreaking Industries of Bangladesh: An Overview and Legal Implication 1, (Llm 304), 1-16.

Hossain, K. A., Iqbal, K. S., \& Zakaria, N. M. G. (2010). SHIP RECYCLING PROSPECTS IN BANGLADESH, (December), 297-302.

Hossain, M. K., Hossain, S. M., Azim, R., \& Meaze, A. K. M. M. H. (2010). Assessment of radiological contamination of soils due to ship breaking using HPGe digital gamma-ray spectrometry system. Journal of Environmental Protection, 1, 10-14. doi:10.4236/jep. 2010.11002.

Hossain, M. M. (n.d.). Ship Breaking Activities and its Impact on the Coastal Zone of Chittagong, Bangladesh: Towards Sustainable Management Young Power in Social Action (YPSA).

Hossain, M. M., \& Islam, M. M. (2004). An EIA case study on the abundance and species composition of fish species in and around Ship breaking area, in the coastal area of Chittagong, Bangladesh. (Unpublished). Institute of Marine Sciences, University of Chittagong, p. 34.

Hossain, M. M., \& Islam, M. M. (2006). Ship breaking activities and its impact on the coastal zone of Chittagong, Bangladesh: towards sustainable management. Young Power in Social Action (YPSA), Chittagong, Bangladesh. pp ix + Available at: http://www.ypsa.org/publications/Impact.pdf. Accessed 21 July 2015.

Hougee, M. (2013). Shades of green in the shiprecycling industry. MSc thesis Environmental Policy Group. Wageningen University Nijmegen, Netherlands.

International Federation for Human Rights (FIDH). (2002). Where do the "floating dustbins" end up? Labor Rights in Ship Breaking Yards in South Asia. 
The cases of Chittagong (Bangladesh) and Alang (India). (Investigative Mission Report). International Federation for Human Rights. No. 348/2, Paris.

Islam, K. L., \& Hossain, M. M. (1986). Effect of ship scrapping activities on the soil and sea environment in the coastal area of Chittagong, Bangladesh. Marine Pollution Bulletin, 17(10), 462-463.

Islam, M.R. (2006). Managing diverse land uses in coastal Bangladesh: institutional approaches. In: C.T. Hoanh, T.P. Tuong, J.W. Gowing \& B. Hardy, eds. Environment and livelihoods in tropical coastal zones, pp 237-248. CAB International.

Jobaid, M. I., Khan, M. M., Haque, a. K. . K., \& Shawon, I. A. (2014). Ship Recycling and Its Environmental Impact: A Brief Overview of Bangladesh. IOSR Journal of Business and Management, 16(10), 31-37. doi:10.9790/487X161013137

Kelly, Tom. (1994). “Toxic Exports: the international waste trade, Green Left”, p. 1. Lipman, Zada. (1998). "Trade in Hazardous Waste: Environmental Justice Versus Economic Growth", supra n. 1998, at 4.

Mohibbullah,M., Molla, M. H., Ali, Kazi,Md. Barkat., Sarwar,Md Iqbal., \& Hossain, N. (2014). European Journal of Advanced Research in Biological and Life Sciences Vol. 2 No. 1, 2014 HEALTH HAZARDS AND RISKS OF SHIP BREAKING ACTIVITIES IN BANGLADESH: AN ENVIRONMENTAL IMPACT ASSESSMENT APPROACH, 2(1), 1-15.

Muhibbullah, M. (2013). Health hazards and risks vulnerability of ship breaking workers : A case study on Sitakunda ship breaking industrial area of Bangladesh ., 2(8), 172-184.

NCSG. (2011). S\&P Monthly reports of N. Cotzias shipping group. URL: http:/ /www.cotzias.gr. Accessed 15 July 2015

NGO Platform. (2014). Annual Report NGO Platform on Ship Breaking 2013. NGO Ship Breaking Platform, 2014.

NGO Ship Breaking Platform. (2015). What a difference a flag makes. NGO Ship Breaking Platform, 2015.

Available at: http://www.shipbreakingplatform.org/shipbrea_wp2011/wpcontent/uploads/2015/04/FoCBriefing_NGO-Shipbreaking-Platform_-April2015.pdf

Nøst, T. H., Halse, A. K., Randall, S., Borgen, A. R., Schlabach, M., Paul, A., ... Breivik, K. (2015). High Concentrations of Organic Contaminants in Air from Ship Breaking Activities in Chittagong, Bangladesh. Environmental Science \& Technology, 49(19), 11372-80. doi:10.1021/acs.est.5b03073 
Pasha, M., Hasan mahmood, A., Rahman, I., \& Hasnat, A. (2012). Assessment of Ship Breaking and Recycling Industries in Bangladesh - An Effective Step Towards The Achievement Of Environmental. Phuket (May).

Paul, Katie, Exporting Responsibility - Shipbreaking in South Asia - International Trade in Hazardous Waste, (2004), Vol. 34/2, Environmental Policy and Law, pp $.73-78$.

Rauscher, Michael. (1999). "International Trade in Toxic Waste", University of Rostock Institute for Economics, Working Paper \#19, p. 3.

Sarraf, M., Stuer-lauridsen, F., Bloch, R., \& Watkinson, R. (2010). Report No 58275-SAS The Ship Breaking and Recycling Industry in Bangladesh and Pakistan, (December).

Sarraf, M., Stuer-lauridsen, F., Bloch, R., \& Watkinson, R. (2010). Report No 58275-SAS The Ship Breaking and Recycling Industry in Bangladesh and Pakistan, (December).

Siddiquee, N. A. (2004). Impact of ship breaking on marine fish diversity of the Bay of Bengal (p. 46). Dhaka: DFIDSUFER Project.

Siddiquee, N. A., Parween, S., Quddus, M. M. A., \& Barua, P. (2009). Heavy metal pollution in sediments at ship breaking area of Bangladesh. Asian Journal of Water Environment and Pollution, 6(3), 7-12.

Talukder, M. I., Fakhruddin, A. N. M., \& Hossain, M. A. (2015). Environmental Impacts of Ship Breaking and Recycling Industry of Sitakunda, Chittagong, Bangladesh, 8(1), 51-58. doi:10.3968/6492

The Economist. (1992). Pollution and the Poor: Why "Clean Development" at Any Price is a Curse on the Third World. February 15.

The Ship Breaking and Ship Recycling Rules. (2011). Rules on Safe and Sound Environmentally Ship Recycling in Bangladesh. Bangladesh Ship Breaking Association. Available at: http://www.bsba.org.bd/page.php?id=23.

Vuori, J. (2013). Environmental Impact of Ship Dismantling: Screening for Sustainable ways. Turku University of Applied Sciences.

Wu, W.-T., Lin, Y.-J., Li, C.-Y., Tsai, P.-J., Yang, C.-Y., Liou, S.-H., \& Wu, T.-N. (2015). Cancer Attributable to Asbestos Exposure in Shipbreaking Workers: A Matched-Cohort Study. PloS One, 10(7), e0133128. doi:10.1371/journal.pone. 0133128

Wu, W.-T., Lin, Y.-J., Shiue, H.-S., Li, C.-Y., Tsai, P.-J., Yang, C.-Y., ... Wu, T.-N. (2014). Cancer incidence of Taiwanese shipbreaking workers who have been potentially exposed to asbestos. Environmental Research, 132, 370-8. doi:10.1016/j.envres.2014.04.026

Young Power in Social Action (YPSA). (2005). Workers in Shipbreaking Industries: A Base Line Survey of Chittagong (Bangladesh), p 21-42. 
Young Power in Social Action (YPSA). (2008). Child breaking Yards Child Labor in the Ship Recycling.

YPSA. (2011). Ship breaking in Bangladesh: ship breaking in newspaper. Available online. http://www.shipbreakingbd.info/ Newspaper_\%20News.html. Accessed 21 July 2015.

\section{Biographical notes of Researchers}

Md Juel Rana Kutub is Lecturer of Geography and served as a Faculty member of a reputed Government college (Faujdarhat Cadet College) of Bangladesh. He has completed his Bachelor of Science and Masters of Science from the department of Geography and Environment, University of Dhaka. He has a multidisciplinary academic background and involved in research works related to climate vulnerability, gender, natural disaster, environmental pollution, land use, groundwater, etc. He won different scholarships for good result during his studies.

Nishat Falgunee has completed her Bachelor of Science and Masters of Science from the department of Geography and Environment, University of Dhaka. She has tremendous result and has got Faculty Deans Award. Now she is doing her $\mathrm{PhD}$ at School of Physical, Environmental and Mathematical Sciences, UNSW Canberra.

Shahreen Muntaha Nawfee has completed her Bachelor of Science and Masters of Science from the department of Geography and Environment, University of Dhaka. She has brilliant result in her education. She is serving as a Lecturer at the Department of Environmental Management, School of Environmental Science and Management, Independent University, Bangladesh.

Yasin Wahid Rabby has also completed his Bachelor of Science and Masters of Science from the department of Geography and Environment, University of Dhaka. He is meritorious student and has a strong research background. He is a PhD student at the University of Tennessee, Department of Geography, Knoxville, TN, United States.

\section{Acknowledgement}

We are grateful to the Bangladesh ship Breaking Association for their strong cooperation during data collection. Our thanks also go to the respondents, those who help us by providing information. Finally, we want to express our gratitude to the Chairman of the department of Geography and Environment, University of Dhaka for giving us the opportunity to use the department lab. 